\title{
Is Egyptian Corporate Financial Reporting Becoming More Conservative?
}

\author{
Ahmed H. Ahmed* and Khaled Hussainey** \\ *Department of Accounting, Faculty of Commerce, South Valley University, \\ P.O Box 83523, Qena, Egypt \\ ** Portsmouth Business School, Portsmouth University, \\ Richmond Building, Portsmouth PO1 3DE, United Kingdom
}

\section{Suggested Citation:}

Ahmed, A. H. and Hussainey, K. (2017). Is Egyptian Corporate Financial Reporting Becoming More Conservative?. Journal of Financial Reporting and Accounting, forthcoming.

\footnotetext{
Abstract ${ }^{1}$ The authors would like to thank Professor Aziz Jaafar, Dr Yasser Eliwa, and the two anonymous referees for their
constructive comments and suggestions.
} 
Purpose - the study aims to compare the level of accounting conservatism amongst the sample companies prior to the 2011 uprising and after that uprising. The study will proceed further to examine the association between accounting conservatism and the level of leverage and profitability of the sample companies covering the same period.

Design/methodology/approach - First, a review of the extant literature on accounting conservatism is undertaken. Second, the sample comprises all of the non-financial companies listed on the Egyptian Exchange. Accounting conservatism is measured using the Market-toBook (MTB) ratio, which is one of the most widely used proxies for determining the extent of accounting conservatism in prior literature. The two-sample $\mathrm{T}$ test has been employed to compare the level of accounting conservatism six years prior to the 2011 uprising and four years following that uprising. Univariate and multivariate analyses have been used to examine the association between some firm characteristics and the level of accounting conservatism amongst the sample companies at the two investigated periods.

Findings - The evidence implies that the sample companies are actually engaging in less conservative accounting policies following the uprising. The results also reveal that data for the first period seems to have greater variations in the first period than in the second period, as can be seen from the values of the standard deviation. The multivariate analysis reported a significant positive relationship between only size and the level of accounting conservatism at both periods.

Practical Implications - We add Egyptian evidence with respect to the directions of accounting conservatism throughout crisis periods, as the majority of prior studies focus on countries with developed capital markets. In addition, the absence of any specific evidence concerning the direction of accounting conservatism during crisis periods, will lead to naïve investors misinterpreting earnings figures and do not realise the actual value of their shares. Therefore, the results reported in this study may encourage those investors to seek out extensive, widely-sourced information regarding investee firms, before deciding whether to hold or sell their holdings. Furthermore, the results presented in this paper should therefore be of interest to regulators and standard-setters charged with developing accounting standards to improve to quality of accounting information.

Originality/value - To the best of authors' knowledge, this is the first and most recent study that examine the level of accounting conservatism amongst non-financial companies in a developing country like Egypt.

Keywords: Conservatism; Financial reporting; Disclosure quality, Egypt

Paper Type: Research Paper

\section{Introduction}


Throughout accounting history, conservatism or prudence concept is one of the key features of corporate information, being in existence for centuries and have been increasing in the last few years (Basu, 1997; Watts, 2003a). Starting this discussion would be more informative by outlining what we mean by accounting conservatism. Bliss (1924) asserted that conservatism is to anticipate no profits but anticipate all losses. This adage simply revolves around "accountant's tendency to require a higher degree of verification to recognise good news as gains than to recognise bad news as losses" (Basu, 1997, p. 7). Similarly, Watts and Zimmerman (1986) contend that being conservation implies that disclosing the lowest value of assets among other possible values, while reporting the highest alternative value for liabilities. The IASC (1989) in its framework asserted that due to uncertainties surrounding many events and circumstances, the preparation of financial statements should be done with prudence. Prudence refers to the inclusion of a degree of caution in the exercise of judgment needed in making estimates under conditions of uncertainty (e.g., assets or income are not overstated and liabilities and expenses are not understated)2.

The main purpose of the current study is to examine whether or not the uprising started in January 2011 in Egypt has led to an increase in the extent of accounting conservatism amongst non-financial companies listed on the Egyptian Exchange (EGX). In other words, the study aims to compare the level of accounting conservatism amongst the sample companies prior to the 2011 uprising and after that uprising. The study will proceed further to examine the association between accounting

\footnotetext{
${ }^{2}$ The terms prudence and conservatism will be used interchangeably in the current study.
} 
conservatism and company size, leverage, profitability and liquidity of the sample companies covering the same period.

Here we can distinguish between two forms of accounting conservatism: conditional conservatism and non-conditional conservatism. Conditional conservatism happens when firms recognises negative economic news in a timelier manner compared to positive ones, examples include accounting for inventory using the lower of its market value and its cost. Conditional conservatism is also known as ex-post, newsdependent, or income statement conservatism. On the other hand, non-conditional conservatism is done by regular under-recognition when reporting the value of net assets, the immediate expensing of research and development expenditures and accelerated depreciation are example of this form of conservatism (Ruch and Taylor, 2015). This is also known as ex-ante, news-independent, or balance sheet conservatism (Beaver and Ryan, 2005; Artiach and Clarkson, 2011). Table 1 highlights examples of the two forms of conservatism.

\section{Table 1: Examples of Accounting Conservatism}

\begin{tabular}{|c|c|}
\hline Forms of & Common Examples \\
\hline Conditional Conservatism & $\begin{array}{l}\text {-Impairment of long-lived tangible and intangible assets } \\
\text {-Immediate expensing of internally generated intangibles } \\
\text { - Inventory recoded at the lower of cost or market price } \\
\text { - Asymmetry in gain/loss contingencies }\end{array}$ \\
\hline Unconditional & $\begin{array}{l}\text {-Accelerated depreciation } \\
\text {-Expensing R\&D expenditures } \\
\text {-LIFO inventory } \\
\text {-Accumulated reserves (e.g., allowance for doubtful }\end{array}$ \\
\hline
\end{tabular}

Source: Adapted from Ruch and Taylor (2015, p. 5). 
Advocates of accounting conservatism claim that conservatism serves as a degree of care when uncertainty prevail and it acts as a hinder of management to report overoptimistic results (Ahmed and Duellman, 2007). Moreover, LaFond and Roychowdhury (2008) argued that more separation between ownership and management creates more needs for conservatism. In the same vein, Lafond and Watts (2008) indicated that accounting conservatism could improve the reliability of the disclosed earnings, as they argue that the management will have lesser options to manipulate and report exaggerated earnings. Furthermore, accounting conservatism is an important mechanism of corporate governance practices and its role in corporate governance is a common theme in the accounting literature (Watts, 2003; Ahmed and Duellman, 2007). In the same context, Zhang (2008) found that conservative firms have a lower cost of debt by obtaining lower interest rates from lenders. Zhang indicated that the benefits of conservatism to lenders come from the fact that conservative firms recognise default risk, which is bad news, in a timelier manner.

Opponents of accounting conservatism argue that conservatism results in biased information and compromises the objectivity of accounting information, which consequently could affect the usefulness of that information in a negative way. In this context, Penman and Zhang (2002) found that unconditional conservatism generates what they called "hidden reserves" that could be eventually released into earnings to achieve management's earnings targets. This implies that accounting conservatism can be employed to facilitate earnings management practices. The conservatism's asymmetric treatment of gains and losses will eventually lead to a systematic understatement in the value of net assets (Watts, 2003a). In this context, Givoly and 
Hayan (2000) indicated that conservative accounting policies have resulted in a regular decline in firm's profitability. Consequently, uniformed investors who fail to realise the true value of their possessions may sell out too soon (Kim and Pevzner, 2010), resulting in a probable loss to this type of investors. This is why the IASB revised conceptual framework eliminates conservatism as one of the qualitative characteristics of corporate information (IASB, 2010). Nevertheless, Watts (2006) argued that accounting conservatism has been growing in accounts over the last decades and it will continue to prevail in accounting practices, as accounting conservatism is a necessary mechanism to overcome uncertainties surrounding today's business environment (Chi and Wang, 2010). With respect to the link between the level of accounting conservatism and economic crises, Francis et al. (2013) found that conservative firms had a better performance during the global financial crisis compared to their counterparts with less conservative accounts. In this regard, it has been argued that crisis periods are characterised with lower levels of earnings management, as firms during crisis will be subject to more scrutiny from interested parties including shareholders, which in turn reduce managers' discretion over earnings (Chia et al., 2007). Furthermore, litigation risk is more likely to increase during economic crisis periods, inducing managers to report more conservative earnings (Jenkins et al., 2009). In support of this view, Huijgen and Lubberink (2005) found that companies operating in high legal liability environment report earnings that are more conservative. Although a substantial body of literature exists on accounting conservatism, not many of these studies focus on the extent of accounting conservatism during crisis periods. 
The evidence reported in the present study implies that the sample companies are actually engaging in less conservative accounting policies following the uprising. The results also reveal that data for the first period seems to have greater variations in the first period than in the second period, as can be seen from the values of the standard deviation. The multivariate analysis reported a significant positive relationship between only size and the level of accounting conservatism at both periods.

This study contributes to the growing literature of accounting conservatism in several ways. First, we add Egyptian evidence with respect to the directions of accounting conservatism throughout crisis periods, as the majority of prior studies focus on countries with developed capital markets. Second, the absence of any specific evidence concerning the direction of accounting conservatism during crisis periods, will lead to naïve investors misinterpreting earnings figures and do not realise the actual value of their shares, ending up selling too soon. This pattern may reflect the fact that private investors in emerging markets are prone to naivety, which could eventually lead to undertaking unwise decisions. Therefore, the results reported in this study may encourage those investors to seek out extensive, widely-sourced information regarding investee firms, before deciding whether to hold or sell their holdings. Third, the current study provides up-to-date evidence concerning the status of accounting conservatism in the Egyptian business environment. Finally, the results presented in this paper should therefore be of interest to regulators and standard-setters charged with developing accounting standards to improve to quality of accounting information.

Egypt was targeted for the present study as an emerging economy with a major influence on other nations in the Middle East and North African (MENA) region as well as its traditionally strong historical relationships with the world's richest nations (Ahmed, 2013). In addition, 
Egypt recently confronted many challenges, before, during and following the January 2011 uprising. The uprising is sought to have a disastrous impact on the economy in general and the EGX in particular; the interruption to commercial activities and general civil unrest led to a prolonged closure of the EGX (EGX, 2012). By the end of 2011, the market had lost E£194 billion of its market capitalisation, as can be seen from Table 2; in January 2011 alone the market lost $21 \%$ of its value.

Table 2: Key Indicators for the Egyptian Exchange

\begin{tabular}{ccccc}
\hline Year & $\begin{array}{c}\text { Number of } \\
\text { Listed } \\
\text { Companies }\end{array}$ & $\begin{array}{c}\text { Number of } \\
\text { Traded } \\
\text { Companies }\end{array}$ & $\begin{array}{c}\text { Market } \\
\text { Capitalisation } \\
\text { (in E£. billion) }\end{array}$ & $\begin{array}{c}\text { Market Cap as } \\
\text { \% of GDP }\end{array}$ \\
\hline $\mathbf{2 0 0 5}$ & 744 & 441 & 456 & 74 \\
$\mathbf{2 0 0 6}$ & 595 & 407 & 534 & 72 \\
$\mathbf{2 0 0 7}$ & 435 & 337 & 768 & 86 \\
$\mathbf{2 0 0 8}$ & 373 & 322 & 474 & 46 \\
$\mathbf{2 0 0 9}$ & 306 & 289 & 500 & 48 \\
$\mathbf{2 0 1 0}$ & 212 & 211 & 488 & 40 \\
$\mathbf{2 0 1 1}$ & 213 & 204 & 294 & 21 \\
$\mathbf{2 0 1 2}$ & 213 & 204 & 376 & 24 \\
$\mathbf{2 0 1 3}$ & 212 & 206 & 427 & 25 \\
$\mathbf{2 0 1 4}$ & 214 & 206 & 500 & \\
\hline
\end{tabular}

Source: The Egyptian Exchange.

Note: The table shows the number of listed companies and market capitalisation, for the Egyptian Exchange over the time period 2005 to 2014.

The remainder of this paper is structured as follows: Section 2 reviews the extant literature in the area, while details about the research methodology and data collection process are presented in Section 3. The results are reported in Section 4. Finally, Section 5 concludes the paper by summarising the findings and identifying future avenues to explore.

\section{Review of the Literature and Hypothesis Development}

A sizeable amount of studies has been undertaken in accounting conservatism in countries with developed capital markets being exclusively the empirical cite, while there is paucity of such studies in developing countries including Egypt. Ahmed and 
Duellman (2007) examined the association between accounting conservatism and board of director characteristics. The sample consists of 306 firms out of the S\&P 500 over the years 1999-2001. The evidence showed that the percentage of inside directors is negatively related to conservatism, while a positive associated was reported with respect to the percentage of outside directors' shareholdings. Bauwhede (2007) investigated the link between credit ratings and the extent of accounting conservatism for a sample of US firms. The study found that high credit ratings were achieved by firms belonging to industries characterised with higher levels of conservatism. Another study in the US undertaken by Wittenberg-Moerman (2008), reported that timely recognition of losses (i.e., conditional conservatism) has an adverse impact on the bid-ask spread. This implies that accounting conservatism could reduce the information asymmetry problem ${ }^{3}$. Ramalingegowda and Yu (2012) sought to examine the link between the level of institutional ownership and conservatism for a sample of 16,911 firm-years over 1995-2006. The sample includes all U.S. public companies with institutional ownership. The results indicated that firms with high institutional ownership are associated with more conservative financial reporting practices. In China, looking at the impact of IFRS on accounting conservatism for a sample of 9863 firm-year observations from China stock market during 2003-2010, Wu and Roberts (2013) reported that the sample firms exhibit less conservative accounting for the period following the introduction of Chinese Accounting Standards (CAS) which converged with IFRS compared to the pre-CAS period ${ }^{4}$. Garcia Lara et al.

\footnotetext{
${ }^{3}$ Information asymmetry occurs when management or insiders possess information that is relevant in assessing future firm performance which is not available to outsiders especially investors and creditors (Ruch and Taylor, 2015).

${ }^{4}$ The convergence came into effect on January 1, 2007.
} 
(2014) examine the consequences of accounting conservatism for a sample of US firms. The study revealed that a negative association between the extent of conservatism amongst the sample companies and bid-ask spread as well as the volatility of stock returns. Investigating the association between the extent of accounting conservatism and the acquisition payment method for a sample of more than 7500 US merger and acquisition deals across the period 1980-2002, Chai and Zhao (2014) found an insignificant negative association between accounting conservatism and the proportion of cash used in the acquisition payment. In the UK, Conway (2014) examined the impact the removal of prudence concept from the revised 2010 conceptual framework for the FTSE100 over the period 2006-2013. The study used the Market-to-Book ratio method and Basu Asymmetric Timeliness model (Basu, 1997). The study provided evidence that the removal of prudence has resulted in a reduction in the levels of accounting conservatism amongst the sample companies. Wang et al. (2014) sought to determine the factors that shape accounting conservatism for private firms in China. In particular, the study investigates whether the information demand of debt holders, state ownership and regional marketization levels affect the accounting conservatism for a sample of 215,388 firm-year observations covering the period 2001-2006. The study found that private firms with more newly borrowed long-term debts adopt more conservative accounting. The results also showed that the accounting information provided by private firms in less developed regions is more conservative than their counterparts in more developed ones. Al-Amri et al. (2015) sought to examine the association between accounting conservatism and cash holdings for a sample of 442 firms representing 6 Gulf Cooperation Council (GCC) countries from 2003 to 2012. The study reported a positive 
relationship accounting conservatism and the amount of cash holdings for GCC firms. Andreou et al. (2015) investigated the impact of accounting conservatism on the credit crash risk amongst a sample of US banks over the period 1995-2010. The study found that conservatism in earnings has significantly limit future credit crash risks of the analysed banks. In the Middle Eastern and North African (MENA) region, Khalifa and Ben Othman (2015) examined the effect of accounting conservatism and the cost of equity capital using a sample of firms from 13 MENA countries during the period 20042007. The results revealed a negative association between accounting conservatism and the cost of equity capital. More recently, Balakrishnan et al. (2016) examined the effect of accounting conservatism on corporate investment during the financial crisis for a sample of US firms. The study revealed that companies with less conservative financial reporting faced a sharper decline in investment activity following the crisis. In addition, the paper reported that more conservative companies experienced lesser drops in both debt-raising activity and stock performance. Although the extant literature on accounting conservatism concerning its direction or the factors that shape it, is inconclusive, theoretical reasoning indicate that accounting conservatism, which is considered a proxy of high quality financial reporting (Wu and Roberts, 2014) may be favourable in crisis periods, since it reduce crash risk ${ }^{5}$. Therefore, the study hypothesises that:

\section{H1: Non-financial companies listed on the EGX are engaging in more conservative financial reporting practices following the January 2011 uprising.}

Table 3 provides a description of the examined variables.

\footnotetext{
${ }^{5}$ In this context, Andreou et al. (2015) asserted that "conservatism with its lower degree of verification to recognise bad news than to good news should offset manager's tendency to hide bad news, and thus conservatism should reduce crash risk" (p. 3).
} 
Table 3: Description of the Investigated Variables

\begin{tabular}{ll}
\hline \multicolumn{1}{c}{ Variable } & \multicolumn{1}{c}{ Description } \\
\hline MTB & $\begin{array}{l}\text { Market-To-Book ratio ((Market Price-High + Market Price-Low / } \\
\text { 2) / Book Value Per Share). }\end{array}$ \\
LOGTASSETS & $\begin{array}{l}\text { Natural logarithm of firm's Total assets (sum of total current } \\
\text { assets, long term receivables, investment in unconsolidated } \\
\text { subsidiaries, other investments, net property plant and equipment } \\
\text { and other assets). }\end{array}$ \\
& $\begin{array}{l}\text { Natural logarithm of firm's Market Capitalisation (Market Price- } \\
\text { Year End * Common Shares Outstanding). }\end{array}$ \\
ROA & $\begin{array}{l}\text { Return on Assets ((Net Income before Preferred Dividends + } \\
\text { (Interest Expense on Debt-Interest Capitalized) * (1-Tax Rate))) }\end{array}$ \\
& / Average of Last Year's and Current Year's Total Assets * 100). \\
& (Short Term Debt \& Current Portion of Long Term Debt + Long \\
LEVERAGE & Term Debt) / Total Assets * 100. \\
& Current Assets-Total / Current Liabilities-Total. \\
\hline
\end{tabular}




\section{Methodology and Data Collection}

This study investigates whether or not non-financial companies listed on the EGX reacted to the January 2011 uprising by adopting more conservative accounting policies. The sample comprises all of the non-financial companies listed on the Egyptian Exchange. After deleting firms with missing data, our final sample includes 115 firms listed on the EGX. We use the Thomson Reuters DataStream database to obtain the data for the investigated variables over the period 2005-2014. As with the prior studies in this area, the outliers of all variables are winsorised to the 5 and 95 percentiles (Francis et al., 2005). Accounting conservatism is measured using the Market-to-Book (MTB) ratio, which is one of the most widely used proxies for determining the extent of accounting conservatism in prior literature (e.g., Beaver and Ryan, 2000; Ahmed et al., 2002; Givoly and Hayn, 2000; Roychowdhury and Watts, 2007, Conway, 2014). As abovementioned, applying conservative accounting policies tend to decrease a firm's book value compared to its market value. Consequently, higher MTB ratios signal a higher level of accounting conservatism and vice versa.

In order to measure the direction of accounting conservatism amongst the sample companies, we compare the level of accounting conservatism six years before the January 2011 uprising (2005, 2006, 2007, 2008, 2009 and 2010) with four years following that uprising $(2011,2012$, 2013 and 2014).

\section{Empirical Tests and Results}

\subsection{Descriptive Statistics}

Table 4 below provides summary statistics regarding accounting conservatism (MTB ratio) and firm characteristics for non-financial companies listed on the EGX. For the purpose of the current investigation, the sample period are divided into two periods; the first period covers six 
years before the January 2011 uprising, while the second period covers four years following the uprising, as mentioned above. The mean value of MTB before the uprising was 2.97, compared with only 1.70 following the uprising, implying that the sample companies are becoming less conservative. The typical firm in the sample had a return of assets of $11.24 \%$ compared with only $6.92 \%$ in the period following the uprising. With respect to the amount of debt and solvency of the sample, Table 4 shows that in the first period the mean values for leverage and liquidity are $15.23 \%$ and $2.20 \%$ respectively, compared with $14.43 \%$ and 3.05 respectively in the second period. Comparing amount of leverage in the two periods reveal little difference this was not the case for liquidity. 
Table 4: Descriptive Statistics for the Sample Companies ${ }^{6}$

\begin{tabular}{|c|c|c|c|c|c|c|c|c|c|c|}
\hline \multirow{2}{*}{ Variables } & \multicolumn{4}{|c|}{ Before the Uprising } & \multicolumn{4}{c|}{ After the Uprising } \\
\cline { 2 - 11 } & Mean & StDev & Min & Median & Max & Mean & StDev & Min & Median & Max \\
\hline MTB & 2.97 & 3.54 & 0.28 & 1.91 & 42.99 & 1.70 & 1.27 & 0.21 & 1.28 & 8.52 \\
\hline LOGTASSETS & 6.43 & 6.91 & 3.75 & 5.70 & 7.75 & 6.56 & 6.98 & 4.55 & 5.86 & 7.78 \\
\hline LOGMCAP & 6.48 & 6.93 & 4.08 & 5.59 & 7.80 & 6.35 & 6.77 & 4.32 & 5.61 & 7.72 \\
\hline ROA & 11.24 & 11.10 & -34.63 & 10.30 & 45.22 & 6.92 & 8.97 & -20.87 & 5.95 & 36.50 \\
\hline Leverage & 15.23 & 17.92 & 0.00 & 7.78 & 79.94 & 14.43 & 17.18 & 0.00 & 7.18 & 65.10 \\
\hline Liquidity & 2.20 & 2.16 & 0.30 & 1.64 & 16.41 & 3.05 & 6.09 & 0.21 & 1.57 & 47.30 \\
\hline
\end{tabular}

Note: This table provides summary statistical information regarding the sample companies before and after the January 2011 uprising. The table shows the mean, standard deviation (StDev), minimum (Min), median and the maximum (Max) values for different variables included in the current analysis.

6 At the end of January 2015, the Egyptian Pound (EE) equalled about 0.1316 US dollars and about 0.085 Pounds Sterling (CBE, 2015). 


\subsection{Findings}

Figure 1 depicts the direction of accounting conservatism amongst the sample companies across the investigated period. The figure shows that the MTB ratio is increasing prior the 2011 uprising until it reached its peak (the mean value was 4.16) in the year ending 2008, which marks the occurrence of the global financial crisis, since then it started sliding and reached the lowest point at the end of 2013 (the mean value was 1.54).

Figure 1: The Direction of Accounting Conservatism over the Period 2005-2014

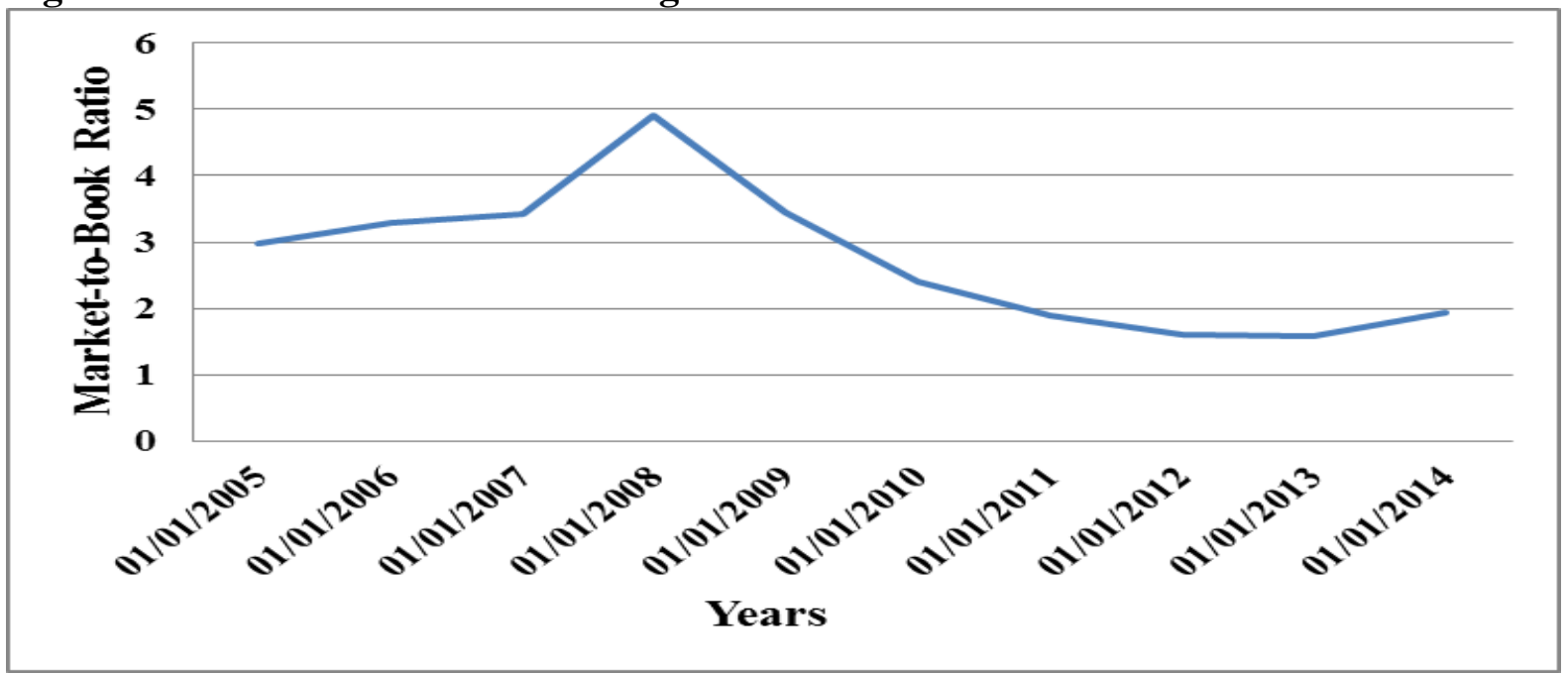

Note: The figure depicts the status of the MTB ratio during the period from 2005 to 2014.

In order to further examine whether or not the accounting conservatism amongst companies listed on the EGX is increasing following the January 2011 uprising, the study run the twosample $t$ test. As mentioned above, the sample period is divided into two sub-periods; the first period represents the period before the uprising which comprise the years 2005 to 2010 and the second period represents the period following the uprising including the years from 2011 to 2014. The study utilised the two-sample t test to compare the mean value of the Market-toBook (MTB) ratio in the first period with its counterpart in the second period. Table 5 reports the results of the two-sample $t$ test. The results show that the mean value of MTB ratio before the uprising is 2.97 compared to only 1.70 in the period following the uprising, as can be seen 
from Table 5 below. This evidence implies that the sample companies are actually engaging in less conservative accounting policies following the uprising. The results also reveal that data for the first period seems to have greater variations than in the second period, as can be seen from the values of the standard deviation (3.54 vs 1.27$)$. The p-value (0.000) of the two-sample $\mathrm{t}$ test indicates that the research hypothesis $(\mathrm{H} 1)$, which assumes that accounting conservatism is increasing following the January 2011 uprising, cannot be supported. Although the current evidence is not in line with the extant literature in this area which expect companies to adopt more conservative policies during crisis periods, it can be linked to the idea that the first period includes in its data sets the years 2007 and 2008 which witness the global financial crisis that hit most of the world. The mean values of MTB ratio for these two years are 3.43 and 4.92 representing the highest values among the data set included in the analysis. These relatively high values for the MTB ratio in both years may trigger the overall mean in the first period compared to its counterpart in the second period. Another explanation of these results could be the fact that, as mentioned before, following the January 2011 uprising companies listed on the EGX encountered many challenges with the market losing more than $21 \%$ of its value in just one month. Consequently, companies may try to alleviate this problem by engaging in less stringent and conservative accounting policies allowing them to signal a good financial performance. In other words, throughout the period following the uprising, non-financial companies listed on the EGX may choose to adopt accounting policies that lead to overstatement of assets and gains and understatement of liabilities and losses, eventually higher but less conservative earnings. Another reason could be linked to the removal of the prudence or conservatism from the IASB revised 2010 Conceptual Framework, as the Egyptian Accounting Standards are mostly converged with accounting standards issued by the IASB. Therefore, non-financial companies listed on the EGX may apply less conservative accounting policies following the removal of the prudence concept. In support of this reason, Wu and 
Roberts (2014) found that Chinese firms adopted less conservative accounting policies following the adoption of Chinese Accounting Standards, which itself are converged with the new version of IFRS.

Table 5: Two-Sample T Test for Comparing the Two Investigated Periods

\begin{tabular}{lcc}
\hline \multicolumn{1}{c}{ Two-Sample T Test } & $\begin{array}{c}\text { Before the Uprising } \\
(\mathbf{2 0 0 5 - 2 0 1 0 )}\end{array}$ & $\begin{array}{c}\text { After the Uprising } \\
(\mathbf{2 0 1 1 - 2 0 1 4 )}\end{array}$ \\
\hline Mean & 2.97 & 1.70 \\
StDev & 3.54 & 1.27 \\
SE Mean & 0.33 & 0.12 \\
T-Value & & 3.60 \\
P-Value & & $0.000^{* * *}$ \\
\hline
\end{tabular}

Note: The table shows the results of the two-sample $t$ test which determine whether the Market-to-Book (MTB) ratio is increasing following the January 2011 uprising. ${ }^{* * *}$ indicates significance at the $1 \%$ level (i.e., ${ }^{* * *}$ p-value $<0.1)$. See Table 3 for variable definitions.

After this analysis the study goes further to examine the impact of firm-specific characteristics on the extent of accounting conservatism amongst non-financial companies listed on the EGX. These characteristics include: company size; leverage; profitability and liquidity. The following subsections provide the results of the univariate and multivariate analyses.

\subsection{Univariate Analysis}

Table 6 below reports the results of the Pearson's correlations between the variable included in the current analysis at the two investigated periods. The findings indicate that size has a positive, but not significant, relationship with the extent of accounting conservatism amongst the sample companies in the period prior to the uprising, similar sign is reported in the periods that follows the uprising, even statistical significance resulted $\left(p\right.$-value $\left.=0.251^{* *}\right)$. This evidence can be linked to the fact that large companies are subject to strict governmental scrutiny, therefore these companies are 
expected to apply more conservative accounting policies. The results also show a negative, but again insignificant, association between and MTB ratio in the first period, while the sign turned to be positive, but not significant, in the second period. This implies that the sample companies with higher percentage of leverage report more conservative earnings. Furthermore, the findings reveal a positive association between profitability in both periods, but it is only the second period where a statistical significance happens $\left(p\right.$-value $\left.=0.264^{* * *}\right)$. With respect to liquidity, Table 6 shows that there are a positive association between liquidity and MTB ration in the first period, compared to a negative one in the second period, but in both cases statistical significance never resulted. 
Table 6: Pearson Correlation between MTB, Size, Leverage, Profitability and Liquidity

\begin{tabular}{|c|c|c|c|c|c|c|c|c|c|c|}
\hline \multirow{2}{*}{ Variables } & \multicolumn{5}{|c|}{ Before the Uprising (2005-2010) } & \multicolumn{5}{|c|}{ After the Uprising (2011-2014) } \\
\hline & MTB & Size & Leverage & Profitability & Liquidity & MTB & Size & Leverage & Profitability & Liquidity \\
\hline MTB & 1.000 & & & & & 1.000 & & & & \\
\hline Size & $\begin{array}{l}0.177 \\
0.059\end{array}$ & 1.000 & & & & $\begin{array}{l}0.251^{* *} \\
0.007\end{array}$ & 1.000 & & & \\
\hline Leverage & 0.076 & $0.264^{* *}$ & 1.000 & & & 0.033 & $0.368^{* *}$ & 1.000 & & \\
\hline & 0.419 & 0.004 & & & & 0.727 & 0.004 & & & \\
\hline Profitability & $\begin{array}{l}0.060 \\
0.527\end{array}$ & $\begin{array}{l}0.189^{*} \\
0.043\end{array}$ & $\begin{array}{l}-0.164 \\
0.079\end{array}$ & 1.000 & & $\begin{array}{l}0.264^{* *} \\
0.004\end{array}$ & $\begin{array}{l}0.014 \\
0.879\end{array}$ & $\begin{array}{l}-0.321^{* *} \\
0.000\end{array}$ & 1.000 & \\
\hline Liquidity & $\begin{array}{l}0.023 \\
0.804 \\
\end{array}$ & $\begin{array}{l}-0.134 \\
0.155\end{array}$ & $\begin{array}{l}-0.301^{* *} \\
0.001\end{array}$ & $\begin{array}{l}0.093 \\
0.322 \\
\end{array}$ & 1.000 & $\begin{array}{l}-0.036 \\
0.699 \\
\end{array}$ & $\begin{array}{l}-0.075 \\
0.423 \\
\end{array}$ & $\begin{array}{l}-0.204^{*} \\
0.028\end{array}$ & $\begin{array}{l}-0.045 \\
0.636\end{array}$ & 1.000 \\
\hline
\end{tabular}

Note: The Table reports the correlations between ESG and other variables investigated in the present study. ${ }^{* *}=$ Correlation is significant at the 0.01 confidence level (2-tailed). ${ }^{*}=$ Correlation is significant at the 0.05 confidence level (2-tailed). For variable description, see table 3 . 


\subsection{Multivariate Analysis}

The results of the univariate analysis suggested a significant relationship between two out of the four variables tested, but this only occur in the period following the uprising, as can be seen from Table 5 above. A multivariate linear regression analysis was therefore undertaken to examine the relationships in terms of causality. The regression equation used is as follows:

$$
M T B=\beta_{0}+\beta_{1} \text { Size }+\beta_{2} \text { Leverage }+\beta_{3} \text { Profitability }+\beta_{4} \text { Liquidity }+\varepsilon_{I}
$$

The results of the regression analysis are presented in Table 6. Regression diagnostics were run to test for multicollinearity amongst the independent variables. As can be seen from Table 6, the figures for the tolerance and variance inflation factor did not reveal any multicollinearity problems. Table 7 indicates that most of the results obtained in the univariate analysis were supported by the regression analysis. The only difference is that, size is significant explanatory variable in the two periods, not only in the second period as reported by the univariate analysis.

Table 7: The Regression Analysis

\begin{tabular}{lccc|ccc} 
Variables & \multicolumn{2}{c|}{ Before the Uprising (2005- } & \multicolumn{3}{c}{ After the Uprising (2011- } \\
& MTB & \multicolumn{3}{c}{ (2n) } \\
Tolerance & VIF & MTB & Tolerance & VIF \\
\hline Constant & $3.587^{* * *}$ & & & $1.262^{* * *}$ & & \\
& 4.165 & & & 5.483 & & \\
Size & $0.000^{* * *}$ & 0.176 & 5.680 & $0.000^{* * *}$ & 0.248 & 4.027 \\
& 4.402 & & & 3.587 & & \\
Leverage & -0.030 & 0.823 & 1.215 & 0.008 & 0.767 & 1.303 \\
& -1.301 & & & 1.010 & & \\
Profitability & -0.044 & 0.851 & 1.174 & $0.036^{* *}$ & 0.814 & 1.228 \\
& -1.004 & & & 2.252 & & \\
Liquidity & 0.019 & 0.903 & 1.108 & -0.002 & 0.941 & 1.062 \\
& 0.094 & & & -0.080 & & \\
No & & 115 & & & 115 & \\
Adjusted R & & 0.120 & & & 0.150 & \\
F Value & & 4.104 & & & 5.000 & \\
\hline
\end{tabular}

Note: The Table shows the results of the regression analysis. For variable description, see Table 3 . ${ }^{* * *}$ p-value $<0.01,{ }^{* *}$ p-value $<0.05,{ }^{*}$ p-value $<0.1$.

\section{Conclusion and Avenues for Future Research}


The present study aims to fill the void in the accounting literature by investigating the status of accounting conservatism amongst non-financial companies listed on the Egyptian Exchange covering the period from 2005 to 2014. In order to examine the whether or not the sample companies engaged in more conservative accounting policies following the January 2011 uprising, the period was divided into two subperiods; the first period covers the years 2005 to 2010, while the second period covers the years 2011-2014. The study adopted the Market-to-Book (MTB) ratio, which is considered an authentic and one of the most commonly used measures of accounting conservatism. To determine whether there are statistical differences in the MTB ratio between the two investigated periods, the study used the two-sample t test. The study goes further to examine the relationship between MTB and company size, leverage, profitability and liquidity running both the univariate and multivariate analyses.

The descriptive statistics show that the extent of accounting conservatism in the period prior to the uprising was nearly two times its counterpart in the period that follows the uprising, this could be linked to the fact that the first period witness the occurrence of the global financial crisis, which is characterised with higher levels of accounting conservatism. The results from the two-sample $t$ test did not support the research hypothesis, as contrary to expectation, the results reveal that the sample companies adopted more conservative accounting policies in the period before the uprising. These results could be linked to the fact the year 2008, which witness the global financial crisis, where companies have higher MTB ratio, were among the timeseries included in the first period, so the high value of MTB ratio may trigger the overall mean of MTB in the first period. Furthermore, taking into account the disruption of business activities following the uprising and in a move to enhance their weakened 
financial performance, companies listed on the EGX may adopt less conservative accounting policies, resulting in higher earnings. Moreover, the removal of the conservatism concept from the revised 2010 conceptual framework of the IASB, may have an impact in this regard. The results of the multivariate analysis indicated that only size that proves to be significantly positively associated with the extent of accounting conservatism amongst the sample companies in both periods, while profitability is only significant in the second period.

Given the paucity of studies that investigate accounting conservatism in developing countries, including Egypt, the current study contributes to the work undertaken in this area where most of the literature has been undertaken in developed countries. The evidence reported in the current paper help in determining the extent of accounting conservatism in Egypt and providing more understanding of how this area of research is moving forward. The current study provide the most up-to-date evidence and use the most commonly utilised proxies in the literature for determining accounting conservatism, resulting in robust evidence that can be replicated elsewhere in the developing world. The results reported in the present study should be of interest to corporate users who should know the reality behind the reported earnings of their investee firms. It should also be of interest to regulators and standards-setters charged with developing refined accounting standards.

Taking into account the fact that the current study is explanatory in nature, as it just focus on determining and comparing the extent of accounting conservatism across two periods, the first expansion could examine the factors that might impact accounting conservatism of the sample companies. Acknowledging the global financial 
crisis, a second expansion could examine the impact of this crisis on extent of accounting conservatism for the sample companies. A third expansion could focus on the impact of the impact of the removal of the prudence concept from the revised 2010 conceptual framework of the IASB on the level of accounting conservatism.

\section{References}

Ahmed, A. H. (2013) Corporate Internet Reporting in Egypt: Practices and Perceptions. Unpublished PhD dissertation, University of Dundee, UK.

Ahmed, A. S., \& Duellman, S. (2007) Evidence on the role of accounting conservatism in corporate governance. Journal of Accounting and Economics 43, 411-437.

Al-Amri, K., Al-Busaidi, M. \& Akguc, S. (2015) Conservatism and corporate cash holdings: a risk prospective. Investment Management and Financial Innovations, Vol 12 (1), pp. 1-12.

Andreou, Panayiotis C., Cooper, I., Louca, C. \& Philip, D. (2015) Does Accounting Conservatism Mintigate Bank's Crash Risk. Working Paper Present at British Accounting and Finance Conference, University Place, Manchester, March 23-25, 2015.

Balakrishnan, K., Watts, R. \& Zuo, L. (2016) The Effect of Accounting Conservatism on Corporate Investment during the Global Financial Crisis. Journal of Business Finance and Accounting Vol 43, pp. 513-542.

Basu, S. (1997) The conservatism principle and the asymmetric timeliness of earnings. Journal of Accounting and Economics 24 (1): 3-37.

Beattya,A., Weberb, J,. \& Yu, J. (2008) Conservatism and Debt. Journal of Accounting and Economics, 45, pp. 154-174

Beaver, W., \& Ryan, S. (2005). Conditional and unconditional conservatism: Concepts and modelling. Review of Accounting Studies, Vol 10(2-3), 269-309.

Bliss, J. H. (1924). Management through accounts. New York: The Ronald Press Co.

Central Bank of Egypt (2015), "Annual report", Cairo, available at: www.cbe.org.eg/ar/Pages/default.aspx (accessed 16 March 2015).

Chai, Q., \& Zhao, H. (2014) Accounting Conservatism and the Choice of Method of Payment in Corporate Acquisitions. Working Paper Presented at British Accounting and Finance Conference, London School of Economics, London, 14-16 April.

Chi, W. \& Wang, C. (2010) Accounting conservatism in a setting of Information Asymmetry between majority and minority shareholders. The International Journal of Accounting, Vol 45(4), pp. 465-489.

Conway, E. (2014) Is UK Financial Reporting Becoming Less Conservative? Working Paper Presented at British Accounting and Finance Conference, London School of Economics, London, 14-16 April. 
Francis, J., LaFond, R., Olsson, P. \& Schipper, K. (2005) The market pricing of accruals quality. Journal of Accounting and Economics, 39(2), pp 295-327.

International Accounting Standards Committee (1989) Framework for the Preparation and Presentation of Financial Statements. IASC, London.

International Accounting Standards Board (2010) The Conceptual Framework for Financial Reporting (The IFRS Framework). IASB, London.

Givoly, D., \& Hayn, C. (2000) The changing time-series properties of earnings, cash flows and accruals: has financial reporting become more conservative? Journal of Accounting and Economics 29 (3), 287-320.

Jenkins, D. S., Kane, G. D. \& Velury, U. (2009) Earnings Conservatism and Value Relevance Across the Business Cycle. Earnings Management: Evidence Based on Hong Kong Firms. Journal of Business Finance \& Accounting, Vol. 36, No. 9-10, pp. 10411058.

Khalifa, M. and Ben Othman, H. (2015) The effect of conservatism on cost of capital: MENA evidence. Applied Economics, Vol 47 (1), pp. 71-87.

Kim, B.H., \& Pevzner, M. (2010) Conditional accounting conservatism and future negative surprises: An empirical investigation. Journal of Accounting and Public Policy, Vol 29(4), pp. 311-329.

LaFond, R. \& Roychowdhury, S. (2008) Managerial Ownership and Accounting Conservatism. Journal of Accounting Research, Vol 46(1), pp. 101-135.

LaFond, R., \& Watts, R. (2008) The information role of conservatism. The Accounting Review 83, 447-478

Penman, S. H., \& Zhang, X. (2002). Accounting conservatism, the quality of earnings, and stock returns. The Accounting Review, 77(2), 237-264.

Ramalingegowda, S. \& Yu, Y. (2012) Institutional ownership and conservatism. Journal of Accounting and Economics, Vol 53, pp. 98-114.

Roychowdhury, S., \& Watts, R. (2007) Asymmetric timeliness of earnings, market-tobook and conservatism in financial reporting. Journal of Accounting and Economics 44, 2-31.

Roychowdhury, S., \& Yu, Y. (2012) Institutional ownership and conservatism. Journal of Accounting and Economics 53, pp. 98-114.

Ruch, G. W., \& Taylor, G. (2015) Accounting conservatism: A review of the literature. Journal of Accounting Literature, Vol 34, pp. 17-38.

The Egyptian Exchange (2012) The Annual Report. EGX, Cairo, Egypt. [online] http://www.egx.com.eg/getdoc/f0d50a9e-058d-4d8c-b6ae-80afb9f398ee/Annual-

Report-2012_en.aspx, accessed on 02/02/2013.

Wang, M., Xiao, J. \& Zhu, J. (2014) What Shape the Accounting Conservatism of Private Firms? Working Paper Presented at British Accounting and Finance Conference, London School of Economics, London, 14-16 April. 
Watts, R. (2003a) Conservatism in accounting. Part I: explanations and implications. Accounting Horizons Vol 17, pp. 207-221.

Watts, R. (2003b). Conservatism in accounting - Part II: Evidence and research opportunities. Accounting Horizons, 17(4), 287-301.

Watts, R. (2006) What has the Invisible Hand Achieved? Available online at: http://ssrn.com/abstract $=879811$, accessed on 10/12/2015.

Watts, R., \& Zimmerman, J. (1986) Positive accounting theory. Englewood Cliffs, NJ: Prentice Hall.

Wittenberg-Moerman, R. (2008). The role of information asymmetry and financial reporting quality in debt trading: Evidence from the secondary loan market. Journal of Accounting and Economics, 46(2), 240-260.

Wu, Z. \& Roberts, C. (2014) Empirical study of the influence of accounting standards on conditional conservatism: Evidence from China. Working Paper Presented at British Accounting and Finance Conference, London School of Economics, London, 14-16 April.

Xu, R., Taylor, G., \& Dugan, M. (2007) Review of real earnings management literature. Journal of Accounting Literature, 26, 195-228.

Zhang, J. (2008) The contracting benefits of accounting conservatism to lenders and borrowers. Journal of Accounting and Economics,

45(1), 27-54 